Navzdory své neuzavřenosti však přináší přehled nejvýraznějších osobností, her i divadelních souborů. Proto může daná monografie sloužit jako velmi užitečný materiál pro ruské filology i divadelní teoretiky. A také pro všechny, kteří se zajímají o proměny současného divadla a umění obecně.

Př́nosem sborníku je především snaha většiny autorů představit nové drama jako medium, které - ač nahlíženo z různých úhlů pohledu - je důležitou součástí dialogu ve společnosti. Autory spojuje často zmiňovaná krize (rus. кризис самоидентификации, кризисное состояние, духовный кризис, кризис слова...) jakožto základní impuls tvorby současných dramatiků. Můžeme jen hádat, nakolik je to přirozená vlastnost umění jako takového - vždy vybírat polemická, provokativní a bolestivá témata - či nakolik je to spojeno s kritickým stavem společnosti na přelomu dvou století.

Anna Danielová

\title{
Literatura:
}

ŽURČEVA, T. V. (red.): Novejšaja drama rubeža XX-XXI vekov: predvaritel'nyje itogi. Samara: Samarskij universitet, 2016.

https://doi.org/10.5817/OS2019-1-12

\section{Книга о метапоэтике Збигнева Херберта}

BOBRYK, R.: Koncept poezji i poety $w$ wierszach Zbigniewa Herberta. Siedlce, 2017. 229 str.

Русский читатель знаком с творчеством Збигнева Херберта, одного из наиболее значительных польских поэтов XX в., по нескольким уже переведенным его книгам (включая эссеистику), по ряду подборок, опубликованных в периодике, отдельных антологиях и в Интернете. В Польше его имя пользуется широким признанием, свидетельство чему - недавно вышедшая книга Романа Бобрыка.

В хербертовском творчестве пристальное внимание к многообразным реалиям мира сочетаются с основательным интеллектуализмом и метафизической рефлексией (в том числе в виде саморефлексии). Неизменный момент самоанализа поэта, его интереса к своему авторскому становлению - 
«поэтической (авто)биографии», в терминологии Р. Бобрыка, - этот момент никогда не закрывал для Херберта путей осмысления «мирности мира» (М. Хайдеггер), т. е. всей сложной реальности вокруг нас, в ее очевидности. Еще Фихте и Гегель отмечали, что саморефлексия обязательно сцеплена с рефлексией об окружающем нас мире, невозможна без этого момента.

Р.Бобрык обобщает квинтэссенцию экзистенциально-художественного опыта поэта в названии-формуле одной из глав своей книги - «Поэт среди птиц и камней» ${ }^{1}$. Анализируются хербертовские обращения к «топосу поэта-птицы» - топосу, заметим, представленному и у Гоголя в венчающем первый том «Мертвых душ» образе «птицы-тройки».

Внимание поэта в его творчестве к различным реалиям допускает постановку вопроса о воздействии на него русского акмеизма и его наследников, «преодолевших акмеизм», по слову Д. Бобышева. Кроме того, Херберт не чужд позднему символизму (в ключе Р. М. Рильке) и сюрреализму, оснащенному, подобно С. Дали, различными культурно-историческими ассоциациями.

Процитируем Херберта:

$[\ldots]$ а моя вторая
плоская голова
отражаясъ на потолке
глядела полная трепета
словно из ложи ангелов
на театр мира
взвихренный
злой
жестокий

я думал тогда

что перед потопом нужно

спасти вещь

одну малую теплую верную так чтоб она пребывала дальше а мы словно в ракушке в ней... ${ }^{2}$

Проблемы метапоэтики (в терминологии М. М.Бахтина, авторской «саморефлексии и самокритики», т. е. в целом отношения автора к своему творчеству) выдвинуты в современном литературоведении в отдельную отрасль относительно недавно. Тем серьезнее те результаты, к которым приходит Р. Бобрык,

1 BOBRYK, R.: Koncept poezji i poety w wierszach Zbigniewa Herberta. Siedlce, 2017, s. 69-102.

2 Пер. В. Булгакова: Zbignev Cherbert. <http://vladivostok.com/Speaking_In_Tongues/herbert.htm>. [online]. [cit. 2. 3. 2019]. 
остро чувствующий поэтическое слово, в том числе в метаописании самого́ этого слова. Слово оценено Р. Бобрыком через внутреннее самосознание этого слова. Проблема самосознания - в главном сугубо философская, что ставит рецензируемое исследование в ряд философско-филологических, даже если сам автор не подразумевал этого непосредственно.

Хотя, по мнению Р. Бобрыка, может показаться, что у Херберта метапоэтика заявлена не вполне очевидно, исследователь оспаривает такой подход. По словам Р. Бобрыка, в хербертовской метапоэтике его как исследователя занимает «создаваемый в [...] стихотворениях образ поэзии и поэта» ${ }^{3}$ : «самыми важными считаются те (аспекты. - С.Ш.), в которых затрагиваются вопросы касающиеся роли и обязанностей поэзии и поэта в мире, или своеобразные автокомментарии к собственному творчеству автора» ${ }^{4}$. Отдавая должное семиотике, но не держась при этом за узкосциентистские или сциентизированные концепты, исследователь оказывается во многом близок к «инонаучной» и «постнаучной» манере современной герменевтики.

С хербертовской метапоэтикой соотнесена в книге и проблема «описания»: «Неспособность описать» - так называется одна из глав, фиксирующая (авто)теорию творческого акта поэта ${ }^{5}$, заявляющего о себе в качестве автора, выступающего «против конвенции» («условности») в искусстве 6 .

Интересны наблюдения в рецензируемом издании над «словесным минимализмом» (термин Р. Бобрыка) Херберта: «Такая установка наиболее отчетлива в стихотворениях Kotatka («Трещетка») и Dlaczego klasycy («Для чего классики»). В первом из названных стихотворений противопоставляются «стаи образов» [«ławice obrazów»], присутствующие в поэзии других авторов и «сухая поэма моралиста» (отождествляемая с евангельским «да будет слово ваше - да, нет нет»); во втором же стихотворении «болтливости» «генералов последних войн» противопоставляется сдержанный и дельный нарратив Фукидида.» ${ }^{7}$

Анализируя «аполлиническую» тему у поэта, исследователь верно замечает: «Но в поэтическом мире Херберта “аполлиническая" модель поэзии получает отрицательную оценку, поскольку она сосредоточивается сама на себе и вообще не занимается проблемами человеческой жизни» ${ }^{8}$.

3 Там же, с. 220.

4 Там же, с. 219.

5 Там же, с. 23-29.

6 Там же, с. 37-58.

7 Там же, с. 221.

8 Там же, с. 220. 
В связи с вопросом о художественной манере поэта (и, в частности, о его отношении к художественному «реализму») см. отдельную публикацию Р. Бобрыка ${ }^{9}$. В финале рецензируемой книги приведен довольно объемный индекс цитируемых произведений Херберта, что само по себе свидетельствует о представительности разбираемого исследователем массива текстов.

Сергей Анатольевич Шульи

\section{Литература:}

BOBRYK, R.: Koncept poezji i poety w wierszach Zbigniewa Herberta. Siedlce, 2017. BOBRYK, R.: Odrealniony realism: $O$ „Trzech studiach na temat realizmu” Zbigniewa Herberta. In: Slavica Tergestina, 2014-2015, vol. 16, s. 66-85.

Zbignev Cherbert. <http://vladivostok.com/Speaking_In_Tongues/herbert.htm>. [online]. [cit. 2. 3. 2019].

\section{Puškinova recepce na Slovensku (1988-2015) a její přesahy}

ELIÁŠ, A., KUSÁ, M., LUKÁČOVÁ, A.: A. S. Puškin na Slovensku (1988-2015). Bratislava: Univerzita Komenského v Bratislavě 2018. ISBN 978-80-233-4465-4.

Recepce literárních jevů se postupně stala slovenskou specialitou - pramenů této orientace je jistě více, ale své slovo tu nepochybně měl koryfej slovenské rusistiky a komparatistiky Dionýz Ďurišin (1929-1997). Ten poukázal na nezbytí alespoň nějaké formy pozitivní diskriminace tzv. malých literatur, $\mathrm{k}$ nimž i česká - poněkud v jiném gardu - také náleží. Recepce cizích jevů je pro takovou literaturu nesmírně důležitá z hlediska udržení co nejintezivnější estetické komunikace a pravda je, i když se to často popírá, že malé literatury spíše přijímají, zejména ve fázi svého novodobého konstituování nebo rekonstituování, než dávají, což není jen jejich problém estetický, umělecký, ale spíše vina okolností: co je malé, má oproti velkému většinou nevýhody, pokud nenajde nějaký asymetrický kompenzační model (což se do jisté míry podařilo literatuře polské, dílem i české). Ruská literatura hrála $\mathrm{v}$ utváření slovenského literárního prostředí klíčovou roli, řekl bych, že mnohem silnější než v českém, jež bylo i v 19. století orientováno na Západ a skrze jeho estetickou „mřižku“ přijímalo -

9 BOBRYK, R.: Odrealniony realism: $O$ „Trzech studiach na temat realizmu” Zbigniewa Herberta. In: Slavica Tergestina, 2014-2015, vol. 16, s. 66-85. 